\title{
MANIFESTO FUTURISME FILIPPO TOMMASO MARINETTI DAN PROGRESIVISME AGRESIF DALAM SEJARAH
}

\author{
Victor Delvy Tutupary \\ Institut Agama Kristen Negeri Ambon \\ *) Email:v.d.tutupary@gmail.com
}

\begin{abstract}
ABSTRAK
Penulisan karya ilmiah yang berjudul "Manifesto Futurisme Filippo Tommaso Marinetti dan Progresivisme Agresif dalam Sejarah" bertujuan untuk memaparkan pemikiran Marinetti mengenai filsafat sejarah dan bagaimana konsekuensinya bagi kesadaran ontologis manusia sebagai makhluk yang menyejarah. Tulisan ini dilatarbelakangi oleh kegelisahan eksistensial mengenai modernitas yang menawarkan perubahan dan kemajuan dengan cepat namun menyisakan lubang kehampaan di dalam diri manusia modern. Penelitian ini merupakan penelitian kepustakaan, yang dilaksanakan melalui tahapan inventarisasi data, pengklasifikasian dan reduksi data, analisis data, dan penyajian data. Data-data dalam penelitian ini dianalisis menggunakan metode interpretasi, heuristika, holistika, dan kesinambungan historis. Manifesto futurisme yang dimaklumatkan oleh Marinetti memandang gerak sejarah secara linier. Alur sejarah selalu bergerak maju ke depan secara progresif agresif dengan menghancurkan tradisi masa lampau. Futurisme menempatkan kecepatan menjadi simbol kemajuan, dan menjadi standar nilai moralitas dan estetis yang baik dan indah, sedangkan kelambanan adalah kejahatan. Futurisme yang progresif agresif dalam seni berhasil membuka ruang kreativitas yang baru dan inovatif, melahirkan aliran-aliran seni avant-garde yang mengubah sejarah estetika. Progresivisme agresif melahirkan invensi teknologi yang cepat dan semakin canggih, sehingga hidup manusia menjadi semakin mudah. Namun, progresivisme agresif mempunyai sisi yang negatif dan destruktif. Kemajuan yang terlalu mendewakan kecepatan, rasio, dan maskulinitas telah menyisakan kekosongan dalam diri manusia modern. Kekosongan tersebut dapat diisi oleh kelambanan yang reflektif untuk mere-evaluasi nilai-nilai hidup dengan menengok kembali pada nilai-nilai luhur tradisi. Kelambanan tersebut menciptakan jeda untuk mengkontemplasikan kembali makna keberadaan manusia dalam arus deras sejarah yang selalu berubah.
\end{abstract}

Kata kunci: futurisme, progresif, agresif, kecepatan, kelambanan

\section{PENDAHULUAN}

\section{Kenangan, Sejarah, Filsafat Sejarah}

Alain de Botton dalam buku How Proust Can Change Your Life ${ }^{l}$ menuliskan sebuah cerita menarik mengenai Marcel Proust ketika mencoba mejawab sebuah sayembara yang diadakan oleh harian L'Intransigeant yang terbit di kota Paris pada tahun 1920-an. Sayembara pertanyaan tersebut berbunyi demikian: Seandainya hari ini adalah hari terakhir dalam hidup anda, bukan karena anda saja yang akan mati besok, tetapi karena besok adalah hari kiamat, lalu apa yang

${ }^{1}$ Alain de Botton. (1997). How Proust Can Change Your Life. (London: Picador). h. 1-2. anda lakukan sekarang? Marcel Proust, seorang novelis tersohor asal Perancis yang menghabiskan sebagian besar hidupnya di atas tempat tidur, memenangkan sejumlah uang sebagai pemenang pertama atas jawabannya terhadap pertanyaan tersebut. Berbeda dengan jawaban para pembaca lainnya, yang menganjurkan untuk melakukan amal saleh, meminta maaf kepada orang-orang yang pernah kita sakiti, bertobat kepada agama, dan perbuatan baik lainnya, Proust justru mengatakan bahwa ia akan berlibur dan menghabiskan waktunya untuk bersantai. 
Jawaban Proust adalah jawaban yang lahir dari pendekatan cara berpikir yang berbeda dalam melihat masa lalu dan masa depan. Bersantai ialah pilihan yang tepat bagi masa depan yang sudah ditentukan dengan kematian, sebab imortalitas atau penghakiman terakhir bukanlah hal yang harus ditakuti karena melampaui akal pikiran manusia. Perbuatan baik di detik-detik terakhir kehidupan bukan saja menunjukkan kepercayaan terhadap kebangkitan jiwa setelah kematian, tetapi juga sekaligus menunjukkan kepanikan dan ketakutan terhadap kematian. Dalam karya monumentalnya Remembrance of Things Past, Proust memperlihatkan bahwa masa depan terlahir dari masa lampau. Apa yang kita inginkan dan lakukan di masa lalu membentuk masa depan kita. Begitu pentingnya arti masa lalu, sehingga apa yang tertinggal di masa lalu tidak hanya sekedar kenangan yang usang dan tanpa makna, tetapi kenangan yang sangat personal, yang dipahami hanya oleh subjek itu sendiri, dan yang hadir dalam bentuk tanda-tanda. Kenangan-kenangan di masa yang lalu tidak lagi sekedar menjadi tanda sebagai representasi dari objek, makna, atau kebenaran, tidak pula dalam pengertian tanda sebagai kendaraan bagi memori, tetapi tanda sebagai entitas pembelajaran. Maka kenangan adalah tanda dari proses belajar yang memengaruhi subjek. Oleh karena itu, bersantai adalah suatu keputusan yang tidak mengingkari masa lalu sebagai proses belajar, tetapi menerimanya sebagai pengalaman yang tidak terelakkan lagi sebagai implikasi dari keputusan pribadi sang subjek yang tidak perlu dipertanggungjawabkan.

Tetapi, meskipun kenangan adalah bagian dari sejarah, ia tidak identik dengan sejarah itu sendiri. Kenangan memiliki kekuatan untuk mendistorsi sebuah kenyataan sejarah menjadi simpul-simpul peristiwa yang hanya dipahami oleh sang subjek. Terdapat stimulus-stimulus yang dapat berupa warna, aroma, bentuk atau beberapa atribut-atribut lainnya yang dapat memicu timbulnya kenangan. Sedangkan sejarah tidak memliki kemewahan tersebut, ia memiliki kekuatan "objektif" yang memaksa setiap orang untuk mengenalnya tanpa harus terlebih dahulu memiliki perjumpaan secara mendalam dan personal. Maka kenangan kerapkali berujung pada keterbungkaman tanpa terbahasakan, sedangkan sejarah berlabuh pada analisis dan spekulasi yang terbahasakan secara naratifdeskriptif. Meskipun demikian, baik kenangan maupun sejarah lahir dari peristiwa-peristiwa yang mewujud dalam ruang dan waktu.

Persistiwa-peristiwa yang memiliki kenangan kadang tampak tidak terlalu berarti bagi orang lain di luar subjek, sedangkan, peristiwaperistiwa dalam sejarah yang dianggap penting dan berarti, secara inheren memiliki syarat-syarat kualitas objektif sebagai palu justifikasi. Kenangan pada akhirnya berhenti pada ketakterbahasakan yang hilang tersesat dalam labirin yang dirajutnya sendiri, sedangkan sejarah selalu terbuka pada analisis dan spekulasi. Di sinilah poin penting dari pembelajaran filsafat sejarah, yakni sebuah usaha untuk menganalisis dan berspekulasi tentang sejarah. Bagaikan seekor burung elang, Filsafat sejarah terbang tinggi, dari atas melihat keseluruhan arus dan gerak sejarah, lalu berusaha menjawab pertanyaan-pertanyaan seperti "what is history?" dan "what is history for?" Voltaire disebutkan sebagai filsuf yang pertama kali menggunakan term "filsafat sejarah", yang saat ini kita artikan sebagai suatu “critical cultural history”. Secara garis besar, untuk mempermudah pemahaman kita, Filsafat Sejarah sejatinya berkenan dengan dua arus besar, yakni yang bersifat spekulatif dan yang bersifat analitis. Ketika sejarah dilihat 
sebagai "objek", maka biasanya hal ini disebut sebagai pendekatan filsafat sejarah yang spekulatif. Ketika sejarah dilihat sebagai sebuah "disiplin", maka hal ini disebut sebagai pendekatan filsafat sejarah yang analitis. ${ }^{2}$

Dari penjelasan tersebut dapat dijabarkan lebih jauh pertanyaan-pertanyaan apa saja yang hendak dijawab oleh kedua pihak. Dalam pendekatan yang spekulatif (atau substantif), berikut contoh-contoh pertanyaan yang hendak dijawab:

...does history demonstrate a single giant unfolding story? If so, does the 'story' have an ending? And is that ending utopian, cataclysmic, or simply mundane? Or does history go round in circles ('cycles')? Can history be divided up into distinct periods such as 'the Dark Ages', and if so, what are they? And what does this tell us about the course of history? Is the history of the world necessarily a history of progress of humanity; if so, why? If not, why not? Do 'laws' govern historical development, or is it already begging the question to see history as 'developing'? Is the course of history determined by forces outside human control, or can individuals' actions make a difference? Can we learn anything from the flow of history, or is every situation unique?

Sedangkan pada pendekatan analitis, demikian contoh-contoh pertanyaan yang hendak dijawab mengenai sejarah:

...what conditions must be met for a statement about the past to be 'true'. Is there an exclusively 'historical' way of explaining the past as distinct, for example, from a scientific way? Is narrative a satisfactory vehicle for historical

2 M.C. Lemon. (2003). Philosophy of History, A Guide for Students. (London-New York: Routledge). h. 7-8.

${ }^{3}$ Ibid. h. 9 knowledge? Do historians implicitly rely on certain 'laws' of human behaviour in their understanding of history? If so, what are they, and are they valid? How far are an historian's perceptions and judgements an extension of his or her own 'unconscious' or ideological views - in other words, can the historian reach objectivetruth, or is he or she captive to subjective accounts? ${ }^{4}$

Apa yang akan penulis paparkan mengenai manifesto futurisme dan progresivisme dalam sejarah lebih cenderung berkenaan dengan pendekatan filsafat sejarah yang spekulatif, yang hendak melihat dan mencari tahu alur gerak sejarah umat manusia yang bekerja dengan ketentuan dan hukum-hukum tertentu, jika ada. Pertanyaan apakah sejarah dunia secara pasti adalah juga sebagai sejarah kemajuan manusia? Progresivisme dengan seluruh argumentasinya membenarkan hal tersebut, sebab kemajuan (progress) adalah rumus utama gerak sejarah. Tulisan ini secara sederhana ingin menjawab apa yang dimaksud dengan manifesto futurisme dan hubungannya dengan progresivisme dalam filsafat sejarah? Kemudian, apa konsekuensi ontologis manifesto futurisme yang dicanangkan oleh Marinetti terhadap kesadaran manusia yang menyejarah?

\section{METODE}

Penelitian ini merupakan penelitian kepustakaan, yang dilakukan dengan cara mengumpulkan pustaka-pustaka yang relevan, membaca, menelaah pustaka-pustaka berupa buku, yang berkaitan dengan pertanyaan penelitian. Proses penelitian dilaksanakan melalui tahapan inventarisasi data, pengklasifikasian dan reduksi data, analisis data, dan penyajian data.

\footnotetext{
${ }^{4}$ Ibid. h. 281
} 
Data-data dalam penelitian ini dianalisis menggunakan metode interpretasi, heuristika, holistika, dan kesinambungan historis.

\section{PEMBAHASAN}

\section{Progresivisme}

Dalam sejarah filsafat, ide tentang kemajuan bukan lagi menjadi hal yang baru. Kemajuan menghasilkan perubahan, sebaliknya perubahan pun dapat menghasilkan kemajuan. Dasar-dasar ontologis "kemajuan" sebetulnya secara implisit telah hadir dan dimulai dalam perdebatan antara dua filsuf Yunani kuno - Herakleitos dan Parmenides.

Herakleitos beranggapan bahwa dunia selalu bergerak dan berubah - pantha rei. Segala sesuatu mengalami perubahan terus-menerus. Perubahan membuat kehidupan dan kematian menjadi lingkaran agung yang berdaya cipta. Kehidupan lahir dari kematian, dan kematian lahir dari kehidupan, "seperti pijar yang muncul dari api, terlahir berkat kematian sesuatu yang lain." 5 Doktrin Herakleitos sejalan dengan adagium terkenal yang mengatakan bahwa tidak ada yang tidak berubah kecuali perubahan itu sendiri.

Perubahan di dalam dunia bagaikan sebuah sungai yang mengalir. Sungai itu tetap ada di sana, namun air yang mengalir melalui sungai itu selalu baru dan berubah setiap saat. Dari momentum ke momentum, sungai itu boleh saja sungai yang sama namun air di sungai itu tak pernah air yang sama. Herakleitos mengatakan bahwa apabila seseorang (atau kita) menceburkan diri ke dalam sungai itu maka, "kita mencebur sekaligus tidak mencebur ke dalam sungai yang sama; kita masih kita, sekaligus bukan kita lagi."6

\footnotetext{
${ }^{5}$ Bertrand Russell. (2002). Sejarah Filsafat Barat. (Yogyakarta: Pustaka Pelajar). h. 55

${ }^{6}$ Ibid. h. 64
}

Di dunia yang fana ini, perubahan adalah sebuah kelaziman. Dov Seidman mengatakan bahwa dunia bukan hanya berubah pesat melainkan juga dibentuk ulang secara dramatis dan mulai beroperasi dengan cara yang berbeda. Perubahan bentuk ini terjadi lebih cepat daripada kemampuan manusia membentuk ulang dirinya, kepemimpinannya, lembaganya, masyarakatnya, dan pilihan etisnya. ${ }^{7}$ Yang menjadi persoalan bukan lagi kecepatan namun percepatan atau akselerasi dari perubahan yang semakin cepat meninggalkan mereka yang lamban dan yang tidak mampu menyesuaikan diri dengan perkembangan zaman. Perubahan yang cepat dan semakin cepat telah menjadi keniscayaan bagi manusia modern. Namun, apakah dunia betulbetul selalu mengalami perubahan terus-menerus seperti yang dikatakan oleh Herakleitos?

Berbeda dengan Herakleitos, Parmenides justru beranggapan bahwa tak sesuatu pun yang berubah. Apa yang telah dianggap berlalu, sebetulnya tidak betul-betul berlalu, tetapi dalam pengertian tertentu masih eksis. ${ }^{8}$ Tidak ada yang baru di bawah matahari.

Plato tidak menolak pendapat Herakleitos maupun Parmenides, tetapi menyintesiskannya. Perubahan selalu berkenan dalam dunia yang kasat mata, sedangkan dalam dunia ide sebagai realitas sejati, segala sesuatu itu tetap dan tidak berubah. Sehingga dapat dikatakan bahwa perubahan dan kemajuan hanya terjadi di dalam dunia kasat mata. Jika ada kemajuan, maka kemajuan itu sebaiknya menuju ke arah yang lebih baik dan ideal seperti halnya duplikat dari yang asli, yang ada di dalam dunia ide.

${ }^{7}$ Dov Seidman dalam Thomas L. Friedman. (2018). Thank You for Being Late, Menapaki Langkah Optimis di Era Akselerasi. Penerjemah Zia Anshor. (Jakarta: PT Gramedia Pustaka Utama). h. 33

${ }^{8}$ Bertrand Russell. (2002). Sejarah Filsafat Barat. (Yogyakarta: Pustaka Pelajar). h. 70 
Aristoteles dalam beberapa hal mewarisi pemikiran ini. Ia setuju dengan gurunya Plato bahwa perubahan dan kemajuan terjadi di dalam dunia ini karena memang hanya dunia ini saja yang kita punya dan yang dapat kita ketahui. Dengan hilangnya dunia ide dalam skema pemikiran Aristoteles, membawa suatu konsekuensi penting bagi pendapatnya tentang alur gerak sejarah yang spiral menuju pada kausa finalis, yakni kebebasan dan kemerdekaan.

Karl Lowith dalam karyanya Meaning in History, pada bab empat memberikan perhatian khusus kepada beberapa pemikir filsafat sejarah yang melihat gerak sejarah sebagai sejarah kemajuan, misalnya pada Proudhon, Comte, Condorcet dan Turgot. Ia membenturkan antara konsep kemajuan (progress) dan konsep pemeliharaan Ilahi (providence). Kemajuan umat manusia tidak bisa berjalan seiring dengan konsep pemeliharaan Ilahi, alasannya sederhana karena Tuhan adalah penghambat kemajuan manusia seperti yang dikatakan Proudhon. Oleh karena itu, manusia harus mengambil alih posisi Tuhan, dan keyakinan akan kemajuan umat manusia harus menggantikan keyakinan akan pemeliharaan Ilahi. 9 Yang menarik dari pemikiran Proudhon, yang dalam beberapa bagian dapat ditemukan dalam pemikiran Feuerbach juga, ia mengingatkan umat manusia akan delusi yang secara inheren melekat kepada aspek mental manusia dalam memahami masalah agama dan ketuhanan. Oleh sebab itu, manusia harus disadarkan dari tidurnya, dan melihat kenyataan yang sebenarnya bahwa pemeliharaan Tuhan tidak lebih dari "insting kolektif" atau "akal universal" manusia sebagai makhluk sosial. Tuhan sejarah adalah hasil karya manusia itu

\footnotetext{
${ }^{9}$ Karl Lowith. (1949). Meaning in History. (ChicagoLondon: The University of Chicago Press). h. 62
}

sendiri, dan "ateisme (humanism)" adalah fondasi dari setiap teodise (theodicy). ${ }^{10}$

August Comte dalam beberapa hal melangkah lebih jauh dari Proudhon dalam menjelaskan gerak sejarah yang selalu menuju kemajuan. Seperti halnya manusia yang tumbuh dan berkembang melalui masa kanak-kanak, remaja dan dewasa, begitu pun perkembangan sejarah peradaban dan pengetahuan manusia bagi Comte. Ada tiga tahap perkembangan, yakni teologis (masa kanak-kanak), metafisika atau abstrak (masa muda), dan yang terakhir tahap ilmiah atau positif (masa dewasa). Dari teologis, metafisis hingga positif adalah tahap-tahap yang harus dilalui dan tidak bersifat siklus atau pengulangan. Progresivisme Comte yang bersifat linier menunjukkan bahwa tahap positif adalah tahap akhir dari kesempurnaan kemajuan. Comte tidak hanya berbicara tentang tipikal kemajuan yang berdasarkan metode saintifik dalam ilmu alam, tetapi dalam ilmu sosial yakni sosiologi. Sehingga kemajuan tidak berhenti pada kemajuan buta yang bersifat ilmiah-materialistik ala Darwin dan pengikutnya hingga neo-Darwinisme Richard Dawkins. Ada roh yang juga terseret ke dalam arus kemajuan yang evolutif, seperti yang ada di dalam pemikiran Teilhard de Chardin dan konsep elan vital-nya Bergson, sehingga tidak sematamata materi yang menggerakkan sejarah seperti yang diungkapkan Karl Marx.

Progresivisme dalam humanisme ateistik Proudhon dan postivistik Comte memang membawa angin perubahan yang tidak sedikit dalam ilmu sosial dan kemajuan ilmu pengetahuan. Sebagai pemicu sebuah kemajuan, Comte dan Proudhon sama-sama menyukai revolusi dan pemberontakan sebagai lakon yang harus dijalani jika ingin tercapai kemajuan yang

\footnotetext{
${ }^{10}$ Ibid.
} 
signifikan dalam sejarah. Revolusi dan pemberontakan (intelektual) inilah yang dilakukan oleh Marinetti dalam bidang seni, ketika pada tanggal 20 Februari 1909, ia mengeluarkan sebuah manifesto futurisme yang radikal, yang dalam perkembangannya tidak hanya berpengaruh dalam bidang seni semata tetapi meluas pada bidang kehidupan yang lain, dan turut membawa progresivisme dalam sejarah ke arah yang lebih agresif.

\section{Manifesto Futurisme}

Manifesto futurisme dan Filippo Tomasso Marinetti adalah dua hal yang tidak dapat dipisahkan. Meski dalam perkembangannya, futurisme sebagai sebuah gerakan revolusi dalam seni dan sosial tidak selalu identik dengan Marinetti, tetapi secara orisinal Marinetti adalah tokoh yang bertanggung jawab atas kelahiran futurisme.

Filippo Tommaso Marinetti lahir pada tanggal 22 Desember 1876 di Aleksandria Mesir. Ayahnya adalah seorang pengacara dari Voghera, sebuah kota kecil di Piedmont, sebelah utarabarat Italia. Ketika terusan Suez dibuka pada tahun 1869 , ayahnya memutuskan untuk mencari peruntungan di Mesir, maka berangkatlah ia pada tahun 1873. Setahun setelah kedatangannya di Mesir, lahirlah anak pertamanya Leone, dan pada tahun 1876 lahir anak keduanya Emilio Angelo Carlo yang sering dipanggil dengan nama Tommaso atau Tom.

Dalam kesehariannya di rumah ia berbicara dengan bahasa Italia, dan mendapat pendidikan Perancis di sebuah sekolah milik Serikat Jesuit di Aleksrandria. Ia pada akhirnya diusir dari sekolah karena menunjukkan ketertarikan yang mendalam dengan karya-karya Emile Zola yang saat itu dimusuhi oleh gereja. Marinetti lalu mengambil studi sastra di Paris hingga mencapai gelar sarjana muda. Setelah itu atas perintah ayahnya,
Marinetti mengambil studi hukum di Universitas Pavia, saat itu keluarga Marinetti sudah kembali tinggal di Italia, yakni di Milan. Studi hukum yang ia jalani berjalan tersendat-sendat dan akhirnya ia pindah ke Universitas Genoa dan berhasil lulus pada tahun 1899 sebagai sarjana hukum namun tetap saja ia tidak tertarik dengan hukum, sebab di dalam darahnya mengalir deras darah sastra yang begitu kuat.

Pada bulan Maret 1898 puisi Marinetti “The Cup-Bearer", untuk pertama kalinya dimuat di dalam Anthologie Revue, sebuah jurnal dwibahasa yang terbit di Milan. Di akhir tahun 1898, puisinya "The Old Sailors" memenangkan sebuah sayembara puisi di Perancis. Marinetti banyak menyumbangkan karya-karya tulisnya dalam jurnal-jurnal. Buku pertamanya The Conquest of the Star, berisi puisi panjang semacam wahyu yang menceritakan perang antara laut dan langit. Sebelum ia mencetuskan Futurisme, ia masih menerbitkan beberapa bukubuku puisi seperti Destruction dan The Carnal City. Marinetti juga menulis dua drama yakni King Hoot dan Electrical Dolls. Pada tahun 1905 ia mendirikan jurnal Poesia (poetry). Pada tanggal 20 Februari 1909 ia menerbitkan Manifesto "The Founding and Manifesto of Futurism" pada halaman depan surat kabar Perancis Le Figaro. Di tahun yang sama ia juga menerbitkan novel Marfarka the Futurist. Marinetti meninggal pada 2 Desember 1944.

Lawrence Rainey ${ }^{11}$ mengatakan bahwa karya-karya awal Marinetti penuh dengan retorika yang menggambarkan kekerasan secara luar biasa, yang ditambah dengan unsur-unsur yang aneh, menakutkan, horor - meski tampak seperti terjebak dalam kemunduran, namun penuh

11 Rainey, Lawrence, Christine Poggi, dan Laura Wittman (Ed.). (2009). Futurism: An Anthology. (New Haven \& London: Yale University Press). h. 3 
ketegangan, melampaui batas dan dengan bebas dapat menyeberang menjadi komik, yang menghasilkan efek yang ganjil. Osilasi antara kegembiraan dan horor menjadi kata kunci dari sebagian besar karya terbaik Marinetti. Tetapi di lain waktu dapat pula menjadi suatu karya yang membingungkan. Tidak heran jika beberapa karya Marinetti menjadi karya yang kontroversial dan tidak dapat diterima oleh publik luas. Novelnya Marfarka the Futurist ditolak di Italia, sedangkan drama-dramanya seperti King Hoot dan The Carnal City, di beberapa tempat gagal dipentaskan hingga selesai. Marinetti memang sosok yang gila dan aneh, tetapi penulis tidak akan membicarakan keanehan tersebut, penulis akan memfokuskan pembahasan pada manifesto futurisme.

Atas permintaan dari Marinetti sendiri untuk mempublikasikan tulisannya yang berjudul "The Founding and Manifesto of Futurism" pada halaman depan surat kabar Le Figaro pada tanggal 20 Februari 1909, telah membawa angin segar bagi perubahan dan kemajuan artistik di dalam seni. Berikut poin-poin dari manifesto futurisme:

1. We intend to sing to the love of danger, the habit of energy and fearlessness.

2. Courage, boldness, and rebelliousness will be the essential elements of our poetry.

3. Up to now literature has exalted contemplative stillness, ecstasy, and sleep. We intend to exalt movement and aggression, feverish insomnia, the racer's stride, the mortal leap, the slap and the punch.

4. We airm that the beauty of the world has been enriched by a new form of beauty: the beauty of speed. A racing car with a hood that glistens with large pipes resembling a serpent with explosive breath...a roaring automobile that seems to ride on grapeshot-that is more beautiful than the Victory of Samothrace.

5. We intend to hymn man at the steering wheel, the ideal axis of which intersects the earth, itself hurled ahead in its own race along the path of its orbit.

6. Henceforth poets must do their utmost, with ardor, splendor, and generosity, to increase the enthusiastic fervor of the primordial elements.

7. There is no beauty that does not consist of struggle. No work that lacks an aggressive character can be considered a masterpiece. Poetry must be conceived as a violent assault launched against unknown forces to reduce them to sub-mission under man.

8. We stand on the last promontory of the centuries! ... Why should we look back over our shoulders, when we intend to breach the mysterious doors of the Impossible? Time and space died yesterday. We already live in the absolute, for we have already created velocity which is eternal and omnipresent.

9. We intend to glorify war-the only hygiene of the world-militarism, patriotism, the destructive gesture of anarchists, beautiful ideas worth dying for, and contempt for woman.

10. We intend to destroy museums, libraries, academies of every sort, and to fight against moralism, feminism, and every utilitarian or opportunistic cowardice.

11. We shall sing the great masses shaken with work, pleasure, or rebellion: we shall sing the multicolored and polyphonic tidal waves of revolution in the modern metropolis; shall sing the vibrating nocturnal fervor of factories and shipyards 
burning under violent electrical moons; bloated railroad stations that devour smoking serpents; factories hanging from the sky by the twisting threads of spiraling smoke; bridges like gigantic gymnasts who span rivers, lashing at the sun with the gleam of a knife; adventurous steamships that scent the horizon, locomotives with their swollen chest, pawing the tracks like massive steel horses bridled with pipes, and the oscillating light of airplanes, whose propeller laps at the wind like a lag and seems to applaud like a delirious crowd. ${ }^{12}$

\section{Agresivitas sebagai Kemajuan}

Membaca apa yang ditulis Marinetti di dalam "The Founding and Manifesto of Futurism", seperti halnya membaca sebuah cerpen yang syarat dengan kata-kata indah yang penuh dengan metafora-metafora. Apa yang penulis cantumkan di atas hanya merupakan potongan dari manifesto futurisme, sedangkan masih ada bagian preambule dan penutup yang ditulis dalam bentuk cerita, yang tidak mungkin penulis cantumkan juga di sini, karena akan memakan tempat yang tidak sedikit.

Manifesto futurisme tidak lahir begitu saja tanpa memiliki latar belakang dan asal-usul. Marinetti melakukan sebuah refleksi ketika melihat sejarah perkembangan seni, ia juga melihat kondisi sosial, politik dan ekonomi yang terjadi pada saat itu, dan sebagai pemikir ia juga melihat sejarah perkembangan intelektual yang sedang melanda dunia saat itu. Hal-hal inilah yang memicu lahirnya manifesto futurisme.

${ }^{12}$ F. T. Marinetti. (1909). "Founding and Manifesto Futurism". Dalam Lawrence Rainey, Christine Poggi, dan Laura Wittman (Ed.). (2009). Futurism: An Anthology. (New Haven \& London: Yale University Press). h. 51-52
Terlepas dari sebab-sebab tersebut, secara pribadi, keeksentrikannya dalam memaknai sebuah insiden kecelakaan yang hampir merenggut nyawanya, disebut-sebut turut memberikan sumbangan besar bagi lahirnya manifesto futurisme.

Manifesto futurisme yang diprokalamasikan oleh Marinetti bukanlah sebuah manifesto picisan yang hanya ingin menjual kontroversi agar menaikkan aras penjualan surat kabar Le Figaro, tetapi manifesto ini sangat berarti karena menjadi dasar dokumentasi dan ideologis bagi lahirnya pergerakan baru dalam dunia artistik, yakni futurisme, di mana terdapat penolakan terhadap masa lalu dan perayaan akan inovasi modernitas dan aksi yang agresif. Ketika ditelurkan, futurisme sebagai sebuah gerakan (movement) telah menjadi bahan perdebatan dan diskusi yang hangat di Eropa. Pada tahun 1909 saja, di Inggris, telah muncul lebih dari lima ratus artikel tentang futurisme yang telah dipublikasikan. Futurisme juga yang harus bertanggung jawab karena turut membidani lahirnya aliran-aliran seni baru seperti vorticisme, dadaisme, surealisme dan lain sebagainya. Virus futurisme pada saat itu mulai menyebar ke dalam berbagai ranah seni seperti sastra, musik, seni visual, arsitektur, drama, fotografi, film, tari, busana, periklanan hingga tata boga.

Futurisme banyak dipengaruhi oleh positivisme yang dibawa Comte hingga filsafat heroisme ala Nietzsche dan konsep elan vital Bergson. Suasana politik dan revolusi yang diperjuangkan George Sorel, dan kesenjangan ekonomi yang pincang antara Italia selatan yang masih agraris dan Italia utara yang industrial, juga telah memengaruhi kelahiran manifesto futurisme.

Manifesto futurisme yang diusung oleh Marinetti melihat kemajuan sebagai sesuatu yang 
tidak dapat dihindari, dan memiliki dampak yang kuat bagi perubahan gerak sejarah.

Futurisme lahir di Italia pada awal abad ke20, ketika era industrial memasuki masa-masa yang paling penting ditandai dengan berbagai penemuan-penemuan berharga seperti mobil, kereta api, pesawat terbang dan beberapa penemuan lain dalam bidang elektronika. Kemajuan industri baja dan batubara meski mengalami kemunduran namun diimbangi dengan kemajuan dalam kimia dan teknologi kelistrikan. Jalan-jalan kota diterangi oleh lampulampu listrik, telegraf, gramofon, dan sinar $\mathrm{x}$, dibukanya rel kereta api Trans Siberian pada tahun 1902, percetakan dan persebaran media massa yang semakin masif dan penemuan sinyal radio oleh Marconi telah membawa perubahan yang besar bagi manusia dalam menjalani kehidupan sehari-hari. ${ }^{13}$ Ruang dan waktu menyusut, kecepatan menjadi identik dengan kemajuan industri modern. Melihat semua kemajuan itu, Futurisme menjadi gerakan yang sadar bahwa kemajuan dan kecepatan merupakan hal yang baik dan tak terhindarkan dalam kemajuan sejarah manusia.

Estetika futurisme melihat yang indah tidak lagi berkenaan dengan standar-standar artistik dari masa lalu, yang indah adalah yang cepat. Seperti pada poin keempat Manifesto Futurisme dikatakan "We airm that the beauty of the world has been enriched by a new form of beauty: the beauty of speed.

Kecepatan tidak hanya menjadi dasar penilaian estetis tetapi juga moralitas. Marinetti menempatkan kecepatan menjadi agama dan standar moralitas yang baru, sebab moralitas Kristen sudah tidak relevan lagi. Moralitas

${ }^{13}$ Joyce Moss. (2005). World Literature and Its Times Volume 7: Italian Literature and Its Times. (Farmington Hills: Gale). h. 162
Kristen yang diniatkan untuk menghadang ekses sensualitas justru menumpulkan dan melawan keseimbangan insting dasar manusia. Maka moralitas kaum futuris sesungguhnya melindungi manusia dari kerusakan yang disebabkan oleh kelambanan, kenangan, dan jeda. ${ }^{14}$ Maka setelah menghancurkan konsep tradisional mengenai kebaikan dan kejahatan, kaum futuris menciptakan konsep kebaikan dan kejahatan yang baru: kecepatan adalah kebaikan, sedangkan kelambanan adalah kejahatan.

Kecepatan adalah tuhan yang baru. Oleh karena itu, simbol-simbol kecepatan, seperti mobil, jauh lebih indah daripada Winged Victory of Samothrace. ${ }^{15}$ Oleh karena itulah senimanseniman dalam gerakan futurisme sering menggunakan mobil, motor atau kereta api sebagai objek estetis, seperti yang terlihat dalam lukisan "Speeding Train" karya Ivo Pannaggi dan "Speed of Motorcycle" karya Giacomo Balla:

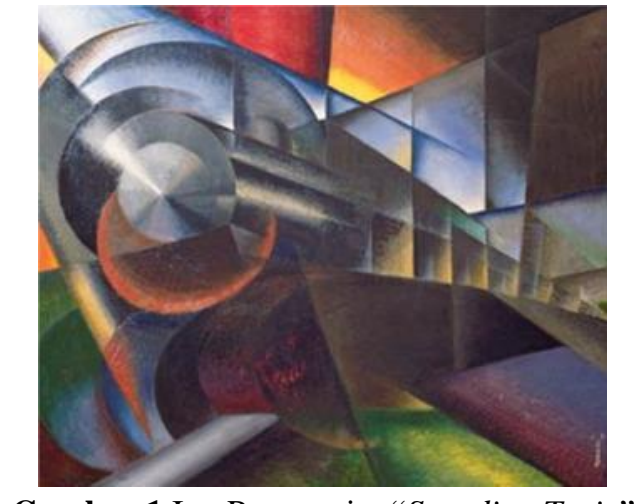

Gambar 1 Ivo Pannaggi - "Speeding Train"

14 F. T. Marinetti. (1916). "The New ReligionMorality of Speed. Dalam Lawrence Rainey, Christine Poggi, dan Laura Wittman (Ed.). (2009). Futurism: An Anthology. (New Haven \& London: Yale University Press). h. 224

15 The Winged Victory of Samothrace adalah patung marmer dari era Helenis yang menggambarkan Dewa Nike, dewa kemenangan dari Yunani. 


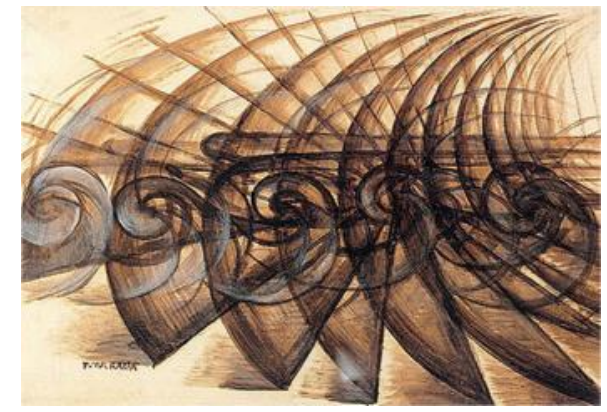

Gambar 2 Giacomo Bala - "Speed of Motorcycle"

Yang menentukan gerak sejarah adalah kecepatan, dan kecepatan adalah jaminan bagi kemajuan. Futurisme melihat kemajuan tidak akan bisa diperoleh jika patokan-patokan, nilainilai, dan kaidah-kaidah dari masa lalu masih digunakan. Kemajuan tidak akan diperoleh jika masa lalu masih terus diingat-ingat dan dijadikan panutan. Oleh karena itu gerakan futurisme membenci para profesor-profesor kolot berkepala botak, para arkeolog, Leonardo da Vinci, Goya, Rembrandt, museum, feminisme, dan bahkan perpustakaan harus dimusnahkan sebab turut melestarikan dan mengajarkan nilai-nilai dari masa lalu yang sudah kadaluwarsa dan tidak dibutuhkan lagi.

Bagi kaum Futurisme, cinta bahaya, keberanian, kemudaan, kekerasan (violence) bahkan perang adalah elemen-elemen yang dibutuhkan dalam mencapai kemajuan. Oleh karena itu, progresivisme kaum futurisme adalah gerakan radikal-agresif yang turut menggunakan hukum-hukum dasar evolusi Darwinian seperti "Survival of the Fittest".

Manusia tidak boleh dibentuk oleh sejarah, tetapi harus membentuk sejarah yang terus bergerak maju. Manusia yang lemah dan sentimental akan tergilas oleh kecepatan kemajuan. Kesuksesan akan dapat dicapai oleh seorang manusia jika ia memahami rumus yang begitu sederhana ini. Pada suatu kesempatan, Marinetti pernah memberikan sebuah nasehat untuk menjadi sukses kepada Fransesco Pratella, seorang komposer yang turut ikut dalam gerakan Futuris: "In order to win over Paris and appear, in the eyes of all Europe, an absolute innovator, the most advanced of all, I urge you to get to work with all your heart, resolute on being bolder, crazier, more advanced, surprising, eccentric, incomprehensible, and grotesque than anybody else in music. I urge you to be a madman". 16

"I urge you to be a madman" adalah katakata Marinetti yang perlu digarisbawahi. Revolusi, penemuan dan kemajuan dalam sejarah dunia selalu dicetuskan oleh orang-orang "gila" atau yang dianggap "gila" oleh masyarakat di zamannya. Kegilaan yang membutuhkan keberanian dan mencintai bahaya. Oleh karena itu, sifat sentimental yang dimiliki seorang perempuan harus dihilangkan karena hanya menghambat kemajuan.

Bagi Marinetti, untuk mencapai sebuah kemajuan terkadang dibutuhkan kekerasan dan perang. Inilah yang menyebabkan dia berafiliasi dengan fasisme yang dibawa Musolini. Spirit membawa Italia ke dalam perubahan dan kemajuan memang menjadi agenda utama fasisme yang cocok dengan spirit futurisme.

Namun, secara umum futurisme berbeda dengan fasisme. Hal ini diungkapkan oleh Giuseppe Prezzolini ${ }^{17}$ bahwa fasisme dan futurisme tidak bisa jalan beriringan, Futurism is the art of free verse, free expression, words-infreedom (indeed, even of abolishing words in tactilism and the art of noises). Fascism, instead,

${ }^{16}$ F. T. Marinetti dalam Lawrence Rainey, Christine Poggi, dan Laura Wittman (Ed.). (2009). Futurism: An Anthology. (New Haven \& London: Yale University Press). h. 4

17 Giuseppe Prezzolini. (1923). "Fascism and Futurism”. Dalam Lawrence Rainey, Christine Poggi, dan Laura Wittman (Ed.). (2009). Futurism: An Anthology. (New Haven \& London: Yale University Press). h. 276-277 
wants schools that will be more rigorous, wants Latin to be required everywhere, and invites us to commemorate De Amicis and Manzoni as representatives of the Italian mind. Fasisme adalah sebuah gerakan nasionalis, sedangkan futurisme adalah sebuah gerakan internasional.

Di dalam manifesto futurisme, pada poin ke9 dan ke-10 walau dalam kata-kata kiasan dan sarat metafora, dapat terlihat bahwa progresivisme futurisme adalah progresisvisme yang radikal dan agresif. Hal ini menyimpan bahaya yang besar jika jatuh pada pemahaman yang salah. Tetapi, sejauh ini agresivisme kaum futurisme tidak menimbulkan revolusi yang berdarah ataupun kekacauan. Futurisme justru membawa perubahan besar dalam bidang seni dan pemikiran manusia modern.

Kenangan, sejarah dan Filsafat Sejarah, seperti yang penulis bahas di awal makalah, dalam konteks progresivisme berkenaan dengan akselerasi kemajuan. Jika kenangan berhubungan dengan hal-hal yang personal di masa lalu, dan sejarah menyangkut peristiwa-peristiwa yang lebih besar mengenai suatu kejadian, maka filsafat sejarah dalam perspektif futurisme membawa entitas-entitas tersebut lepas dari kebekuan keabadian kenangan menuju pada kemajuan yang tercerahkan dari masa lalu yang stagnan. Progresivisme agresif futurisme melihat masa depan dibentuk oleh keinginan futuristis manusia. Sejarah bergerak maju secara linier, dan tidak menuju suatu apa pun yang ideal, dengan lain kata tidak ada kausa finalis Aristotelian, atau digerakkan oleh entitas transendental seperti halnya roh absolut Hegel. Kemajuan tidak mengenal zaman, kemajuan yang satu disusul oleh kemajuan berikutnya. Kemajuan yang cepat adalah rumus agung sejarah. Marinetti pernah mengatakan bahwa suatu saat apa yang dilakukannya ini akan dianggap usang oleh generasi muda yang baru, dan menggantikannya dengan yang lebih baru, tetapi memang hal itulah yang diinginkan kaum futurisme.

\section{Kritik}

Ada beberapa kritik yang dapat dilontarkan mengenai manifesto futurisme Marinetti. Apabila futurisme Marinetti memuja kebaruan, kecepatan, kegilaan, dan agresivitas sebagai yang indah, namun apakah akselerasi perubahan yang progresif dan agresif adalah satu-satunya jalan untuk mencapai kemajuan? Apabila kemajuan adalah kekuatan untuk menguak masa depan, maka apakah kekuatan tersebut membawa dampak yang serius bagi kesadaran ontologis manusia sebagai makhluk yang menyejarah? Apakah kelambanan sebagai "dosa" di era stabilitas statis merupakan tanda kelemahan?

Gerak aktif adalah ciri kehidupan. Sesuatu yang berhenti bergerak berarti berhenti hidup. Aristoteles berkata bahwa hidup adalah gerakan. Namun bergerak tidak selalu berarti bergerak dengan cepat atau sangat cepat. Teknologi memang bergerak dan berkembang dengan sangat cepat. ${ }^{18}$ Kecepatan menjadi tanda kemajuan. Namun yang menjadi persoalan adalah justru kecepatan itulah yang menjadi sumber banyak masalah saat ini.

Kecepatan membungkam keheningan refleksi yang mendalam. Kecepatan yang "menghancurkan" buku-buku di dalam perpustakaan, dan barang-barang antik di dalam museum adalah kecepatan yang menutup lubang sumur historisitas di mana makna dan nilai-nilai tradisional dapat ditimba. Ada saat di mana kelambanan dibutuhkan manusia modern untuk merefleksikan dirinya, juga untuk mereevaluasi

${ }^{18}$ Misalnya di dalam dunia industri mikroprosesor dikenal Hukum Moore yang meramalkan tentang laju perkembangan mikroprosesor dalam setahun. 
semua nilai, melambat sejenak untuk melihat apa yang terlupakan, tertinggal dan tercecer akibat kecepatan.

Kuntowijoyo dalam cerpennya "Dilarang Mencintai Bunga-Bunga" mengkritik kehidupan manusia modern yang cepat, mekanis, kaku, maskulin, artifisial, dan terlalu mengandalkan rasio, lantas menyisihkan rasa dan perasaan. Manusia modern lebih suka pada gesekan besi dan percikan api ketimbang gesekan bunga dan daun di taman ketika angin sepoi-sepoi bertiup. Itulah mengapa manusia modern seperti dilarang untuk mencintai bunga-bunga sebagai simbol rasa, kelembutan, kelambanan, keindahan alamiah, dan feminitas.

Kecepatan yang agresif dan maskulin melihat dunia seperti medan perang. Orang-orang hebat haruslah bertangan besi, keras, dan gila. Valentine de Saint-Point, ${ }^{19}$ yang juga seorang futuris, merespon konsep maskulinitas Marinetti dengan menyatakan bahwa orang-orang hebat dan jenius adalah hasil dari perpaduan yang simultan dari elemen-elemen feminitas dan maskulinitas.

Krisis akibat teknosentrisme manusia modern adalah perkara yang rumit, karena di satu sisi, kemajuan teknologi dibutuhkan untuk memudahkan hidup manusia dan memuaskan kuriositas manusia, namun di sisi lain semakin canggih teknologi malah semakin membuat manusia teralienasi, tercerabut dari akar kemanusiaannya. Semakin menakutkan, karena dengan kemajuan infotek dan biotek, kemanusiaan hendak didefinisikan ulang.

${ }^{19}$ Valentine de Saint-Point. (2009). "Manifesto of the Futurist Woman (Response to F. T. Marinetti)", Dalam Lawrence Rainey, Christine Poggi, dan Laura Wittman (Ed.). Futurism: An Anthology. (New Haven \& London: Yale University Press). h. 110
Kelambanan bukanlah sebagai sebuah kejahatan. Kelambanan sebagai sebuah jeda untuk berefleksi dan berkontemplasi justru menjadi oasis yang sangat penting di tengah laju percepatan dunia yang cepat. Pertanyaan ontologis tentang makna kesadaran manusia berikut arti keberadaan manusia di tengah dunia akan sulit diperoleh jika kecepatan, rasionalitas, dan maskulinitas menjadi dewa penentu arah sejarah.

\section{KESIMPULAN}

Manifesto futurisme yang dicanangkan Filippo Tommaso Marinetti melihat alur sejarah sebagai sebuah gerakan linier progresif. Progresivisme sejarah ala futurisme yang termaktub di dalam manifesto futurisme Marinetti adalah gerakan sejarah yang progresif agresif, maskulin, keras, dan membenci tradisi yang lama dan lampau. Gerak sejarah yang progresif agresif melihat kemajuan sebagai sebuah kebaikan yang harus dicapai melalui kecepatan, sedangkan kelambanan adalah sebuah kejahatan. Kecepatan dibutuhkan agar transformasi ide dan kemajuan dapat dicapai. Status quo yang dikukuhkan oleh tradisi dihancurkan demi sebuah penemuan baru dan pembebasan ide. Progresivisme agresif yang ditawarkan oleh manifesto futurisme Marinetti mendewakan kecepatan sebagai standar nilai moralitas yang baik dan yang indah secara estetis. Pada sisi lain, kelambanan dianggap sebagai kejahatan.

Dalam dunia seni, futurisme menuai rekasi yang positif dengan lahirnya aliran-aliran seni baru yang kreatif dan berani, namun ada konsekuensi negatif dalam perspektif yang lebih mendasar yakni tentang bagaimana kesadaran ontologis manusia dibentuk melalui akselerasi yang progresif agresif. Invensi teknologi yang progresif agresif tidak lagi bersifat konstruktif 
namun desktruktif bagi pencarian kesadaran akan makna dan arti keberadaan manusia di tengah segala kemajuan yang diperoleh.

Negativitas futurisme yang progresif agresif meninggalkan lubang kosong dalam diri manusia modern, lubang yang dapat diisi oleh progresivisme yang masih menghargai kemajuan tetapi tidak mendewakan kecepatan. Ada ruang bagi kelambanan reflektif untuk mere-evaluasi semua nilai yang destruktif. Ada jeda untuk mengkontemplasikan kemajuan dalam arus deras sejarah yang lebih berperasaan, feminin, dan lebih mencintai bunga-bunga.

\section{DAFTAR PUSTAKA}

De Botton, Alain. (1997). How Proust Can Change Your Life. London: Picador.

Friedman, Thomas L. (2018). Thank You for Being Late, Menapaki Langkah Optimis di Era Akselerasi. Penerjemah Zia Anshor. Jakarta: PT Gramedia Pustaka Utama.

Lowith, Karl. (1949). Meaning in History. Chicago-London: The University of Chicago Press.

Lemon, M.C. (2003). Philosophy of History, A Guide for Students. London-New York: Routledge.

Marinetti, F.T. (1909). "Founding and Manifesto Futurism". Dalam Lawrence Rainey, Christine Poggi, dan Laura Wittman (Ed.). (2009). Futurism: An Anthology. New Haven \& London: Yale University Press.

Marinetti, F.T. (1916). "The New ReligionMorality of Speed. Dalam Lawrence Rainey, Christine Poggi, dan Laura Wittman (Ed.). (2009). Futurism: An Anthology. New Haven \& London: Yale University Press.

Moss, Joyce. (2005). World Literature and Its Times Volume 7: Italian Literature and Its Times. Farmington Hills: Gale.
Prezzolini, Giuseppe. (1923). "Fascism and Futurism". Dalam Lawrence Rainey, Christine Poggi, dan Laura Wittman (Ed.). (2009). Futurism: An Anthology. New Haven \& London: Yale University Press.

Rainey, Lawrence, Christine Poggi, dan Laura Wittman (Ed.). (2009). Futurism: An Anthology. New Haven \& London: Yale University Press.

Russell, Bertrand. (2002). Sejarah Filsafat Barat. Yogyakarta: Pustaka Pelajar. 